\title{
Basketball, Books, And Brotherhood: Dewitt Clinton High School as Scholastic Model of Postwar Racial Progression and African American Leadership
}

\author{
Arthur Banton \\ Department of History \\ Tennessee Technological University
}

Abstract: In 1950, the City College of New York (CCNY) became the first racially integrated team to win the national championship of college basketball. Three of the players on that team, Arthur Glass, Mike Wittlin, and Ed Warner, attended DeWitt Clinton High School in the Bronx, New York. At the time Clinton High School was one of the most academically rigorous public schools in the city and the United States. During this postwar period, nearly one third of Clinton graduates attended college at a time when the national high school graduation rate stood at $20 \%$. Unlike most high schools in the United States, Clinton was racially integrated with more than $20 \%$ of the student body identifying as African American. Like their contemporaries, Black students were encouraged to pursue opportunities that seemed unthinkable in an era of racial stratification. As a result, Clinton produced several Black students armed with the skills to navigate the terrain of prejudice and other social barriers. DeWitt Clinton High School was a model for interracial brotherhood while also fostering Black leadership. The Black athletes who attended CCNY were better prepared for the transition of competing on a racially integrated college team, can be partially attributed to their secondary schooling at DeWitt Clinton. This article examines the racial climate of DeWitt Clinton during the postwar years when the three young men were in attendance and how it fostered a culture of Basketball, Books, and Brotherhood.

Keywords: basketball, high school, integration, African American, New York City

\section{Basketball, Books, and Brotherhood}

Since its inception as Boys' High School in 1896, Dewitt Clinton High School (located in the Bronx, New York) was a multicultural, academically rigorous high school with exceptional varsity athletic programs. The institution fostered an egalitarian environment that promoted brotherhood which enabled all students to excel and ascend to various levels of leadership. This experience was essential in preparing them to lead their communities and a racially progressive society. In addition to fostering a culture of academic success, Clinton also produced a number of successful varsity athletic programs, particularly in basketball. Between 1905 and 1947, the basketball team won twelve New York City Public School Athletic League (PSAL) championships, an average that amounted to one every three point five years.

Located in the Northwest Bronx, DeWitt Clinton High School was named after the only man who would serve as mayor and governor of New York State and as a Presidential candidate in 1812. As a young man whom graduated from Columbia College at seventeen and law school at 
twenty-one, Clinton was a staunch supporter of public education who worked tirelessly to ensure that all children has access to a high-quality education (Cornog, 1998: Pelisson, 2009).

In 1900, when the faculty and students at Boys' High decided to rename their school, they chose the one individual who was instrumental in establishing public schools in New York City. After spirited debates and discussions, the Boys' High School of Manhattan and the Bronx was renamed DeWitt Clinton High School (Pelisson, 2009).

\section{Consolidated School Law}

On April 18, 1900, one of the most prominent bills to address racial discrimination and inequality in education was signed into law. New York State Governor Theodore Roosevelt signed a bill entitled, " the Consolidated school law," which barred the use of race or ethnicity as a marker for admission to New York State public schools. This superseded a previous bill from 1894, that permitted local school boards to "establish a separate school or separate schools for instruction of children and youth of African descent, resident therein, and over five and under twenty-one years of age; and such school or schools supported therein for White children and they shall be subject to the same rules and regulations and be furnished facilities for instruction equal to those white schools therein." The abolishment of this law occurred at the time when New York State was in the middle of a 40-year population surge in which the number of residents increased from five to 10 million (Brooklyn Eagle Almanac, 1922; Daniels, 2002; New York Legislature, 1900).

The Consolidated School law barred race and identity as criteria for school admission but did not eliminate actions based upon racial prejudice. Prior to 1898, each of the boroughs operated their own school systems. After the consolidation and unification of New York City, Roosevelt promoted equality. Roosevelt believed that education was a way for citizens to improve their political, social, and economic standing. There was little publicity about the passage of the bill. Interestingly, there was no mention of the new law until after it had passed. Dismantling legalized segregation would become one of notable highlights during Roosevelt's brief two-year term as governor (Ravitch, 1974).

Located on $13^{\text {th }}$ Street in Manhattan, Boys' High School was established as a vehicle to a high caliber of intellectually enriched education. Throughout the years it would amass a list of accomplished alumni in a variety of fields rivaled by few high schools, including Ira Berlin, Neil Simon, Ralph Lauren, Burt Lancaster, Richard Avedon, A.M. Rosenthal, Nate Archibald, and Robert Hofstadter (Pelisson, 2009).

Between its inception and 1906, five annexes were established throughout Manhattan to accommodate the 12,000 students. Recognizing that a larger facility was needed, the Board of Education authorized the construction of a new building that opened on Mosholu Parkway in the Bronx in 1929. This location would serve as part of a mile-long educational center that, by 1940, included: an elementary school; (Walton, a co-educational high school, and the Bronx High School of Science); a Museum of Peaceful Arts; and a Hunter College satellite campus (which would be renamed Herbert H. Lehman College in 1968). At the time of relocation, the main building enrolled 6,275 students (even though its capacity was 5,124) who commuted from all five boroughs of New York City. Multiple day sessions were created in order to handle the overpopulation. Despite the overcrowding and concerns about safety, the school did not compromise the quality of education a point constantly ingrained into the student body. On numerous occasions, school publications 
boldly stated, "Students who are not planning to go to college will be asked to leave DeWitt Clinton High School” (New York Times, 1927; Pelisson, 2009).

The ideology of college as an essential destination espoused by the student body was more impressive when considering that it had been slightly over a decade since secondary education was normalized. Prior to the founding of Boys' High School in 1896, New York City did not have a have high school. It wasn't until the Great Depression of the 1930s and the lack of jobs that high school became a viable option en masse. World War II temporarily disrupted that narrative and made job opportunities for youth available once again. However, it wasn't until after World War II that the idea of high school was accepted and supported as the conventional course for youth who were now being recognized by the recently adopted term teenagers (Hine, 1999).

Clinton was able to attract talented educators - a significant number of them held doctorate degrees. For consideration of employment, a faculty member had to score in the top percentile in their respective subject area on the city-administered examination. Clinton was also able to benefit from a surplus of educators who could not find university positions due to the economic restraints of the Great Depression. As a result, Clinton students were the beneficiaries of some talented and dedicated, but overqualified educators. In many respects, DeWitt Clinton bore a resemblance to the City College of New York (CCNY), an institution of higher education that also enveloped high academic standards to a level in the 1930s where it was dubbed "Harvard on the Hudson" and "The poor man’s Harvard" (Arenson, 1999; Bard, 1975; Lemming, 1994, p. 26).

In early-to-mid-20 Century it was rare to have Black teachers in schools instructing predominately White students - especially one with a rigorous curriculum and reputation. The fact that DeWitt Clinton employed Jessie Redmon Fauset to teach French and English literature speaks volumes about the school's position on racial equality and brotherhood. Fauset attended Cornell on a scholarship and received her M.A. from the University of Pennsylvania in 1919. Referred to as the "mother of the Harlem Renaissance," she was the literary editor of the Crisis (1919-1926), where she nurtured the careers of Black writers such as Claude McKay, Countee Cullen, and Jean Toomer. During her 17-year tenure at Clinton, she published four novels and for a brief period, cofounded and edited, the Brownies' Book, a monthly magazine whose objective was to instill and reinforce self-esteem in Black children. Though aimed at Black children, its mission was to "seek and teach Universal Love and Brotherhood for all little folk-black and brown and yellow and white." Her initiatives suggest that she was certainly a role model and a possible mentor to Black students. Equally important is that her credentials reflected those of a university professor as opposed to a high school teacher. Administrators at the school realized she was an invaluable asset and hired her based on her credentials. Her narrative underscores the quality of the instructors at the school (Andrews, 2001; Bracks, 2014).

The similarities between the two institutions start with leadership. During the postwar years, principal Dr. John Walsh, a CCNY alum, continued a scholastic agenda that ensured Clinton students could successfully navigate CCNY's rigorous entrance exams. In 1938, Clinton had an enrollment of 7,700 students that attended three overlapping sessions from 8:05AM to 5:26PM. Overcrowding was a serious issue that unfortunately wasn't resolved until the 1970s, when the New York City Board of Education decided to construct several high schools to service students in the Bronx and Upper-Manhattan (Andrews, 2001; Bracks, 2014; Buder, 1972). 
The predominately White esteemed faculty cultivated the dreams of their students, which had an especially pronounced effect on African Americans. Though he had to overcome challenges before receiving his degree in Architecture from New York University (NYU) in 1943, Percy Ifill, who designed the Adam Clayton Powell Jr. Office State Building in Harlem, credits his experience at Clinton for inspiring him to pursue his dreams. Other accomplished African Americans who graduated from Clinton prior to postwar years include: Shelton Hale Bishop ('07), who served as the rector of the largest African American Episcopal church in the United States (U.S.) advocated for desegregation in the Civil Rights Movement; Wilmer Lucas ('15), the first African American Certified Public Accountant in New York State; James Latimer Allen ('23), a renowned photographer who captured many of the images from the Harlem Renaissance; Dean Dixon ('32), the first African American to conduct the New York Philharmonic; Robert Lowery ('34), the first African American to serve as Fire commissioner of a major U.S. city; and August Martin ('38), the first African American commercial pilot (Jet, 1972; 1973; Martin \& Lowery, 2001; Pelisson, 2009; Schomburg Center for Research in Black Culture).

The positive experiences of Black students at Clinton impacted future generations of boys who were looking for an institution that fostered a culture that would allow them to develop the intellect and perseverance necessary to reach their goals. The advice of alumnus Countee Cullen ('21) inspired a 13-year-old James Baldwin to apply to Clinton. In addition to writing poems and novels, Cullen also served as an instructor at Frederick Douglass Junior High School in Harlem. Baldwin's experience at Clinton broadened his intellectual and creative development. Like Cullen, he served as editor of the Magpie, the school's literary magazine, and developed an interracial network of close friends. Within this network, he engaged and initiated discussions about literature, politics, history and religion (Lemming, 1994).

\section{The Relationship between Athletics and African American Leadership}

On October 3, 1947, six months after Jack Roosevelt Robinson integrated the national pastime of professional baseball with the Brooklyn Dodgers, DeWitt Clinton High School circulated a petition that protested racial discrimination in educational institutions to be delivered to Washington D.C. In doing so, it became one of the first schools to make such a bold and visible statement. The General Organization (G.O.) student body president Stan Langer (who was not African American) invited other high school leaders to join Clinton's fight for equal education or adopt similar initiatives. Langer noted, "We hope soon to have every New York City high school swamping Albany (the state capital of New York) with petitions demanding that legislation be enacted to do away with racial, religious and regional discrimination in all New York colleges and universities" (Clinton News, 1947, p. 1.) This groundbreaking initiative exalted Clinton High School to a status that few peers could emulate. These actions reaffirmed DeWitt Clinton as a model of racial progressivism and a promoter of brotherhood. Several students and faculty utilized their unique status to push for racial progression. These students understood the value of racially integrated settings, and most importantly, established alliances and friendships with persons of ethnic and racial backgrounds different from their own. The school formerly known as Boys' High was developing students into men and leaders of society.

In the fall of 1947, Pete Taylor ran for the soon-to-be-vacant position of class president that December. In a letter published in the Clinton News, Taylor who presently served as class secretary, highlighted some of his accomplishments. Most notable was the circulation of surveys to the student 
body for ideas to improve their high school experience. He also noted that many of these tangible ideas were implemented by student government or in the early stages of execution. In essence, Taylor presented himself as a candid and vocal representative for the student body. (Clinton News, 1947).

On Thursday, January 15, 1948, the student body elected Taylor, an African American, as the General Organization (G.O.) class president by a margin of 1,340 votes over his closest rival. Taylor's election was one of the largest margins of victory for class president in the school's history. It is estimated that $65 \%$ of all students were members of the G.O. With Taylor winning $56.3 \%$ of the ballots, he more than doubled the popular vote over the other two candidates by receiving 2,189 out of a possible 3,884 votes. Though uncertain, Taylor was in all-likelihood the first Black elected class president in the school's 52-year history. However, one certainty was that his campaign promises noted in the school paper certainly resonated with the student body. He noted, "As a Presidential candidate, I will promise just one thing: a democratic government of students, actually functioning for the desires of all G.O. members" (Clinton News, 1947).

Taylor's statement suggests there might have been issues of leadership with the previous administration in servicing the needs of G.O. members and the student body. Taylor presented himself as the person to bridge the divide who would lead an administration inclusive of all. Though unclear, his statement coupled with an analysis of published reports suggests that a member of the student body had to join the G.O. in order to participate in student clubs/organizations and vote in elections for student government. (Clinton News, 1948a).

In a post-campaign interview, Taylor used athletics to push forward the notion of solidarity to victory. He noted, "The G.O. supports every activity to the hilt. Last year for example we devoted $\$ 3,300$ to athletics." He continued, "We need the help of every student in this school if we're to continue our work. A football team can't be equipped without a large expenditure. Every organization requires funds. I feel that the least the students can do is support the G.O. We need everyone's cooperation" (Clinton News, 1948b).

Taylor also addressed the benefits of joining the G.O., but also brought into conversation Clinton's legacy as a means of spurring interest in joining. He noted that Clinton students had historically had one of the leading active G.O.s in the city and emphasized the need to continue that tradition. Taylor's use of athletics was brilliant for a variety of reasons. First, he mentioned football because the previous season, the team had just won the city championship game after the Public School Athletic League (PSAL) temporarily suspended competition during the war (this was partly attributed to rations on materials and financial restraints). Clinton won the title due in part to the contributions of Whitney Arceneaux, an African American and Navy veteran originally from New Orleans, who was voted second team All-City - a well-publicized accomplishment not lost on the student body. Secondly, the focus on athletics brought into conversation school pride, accomplishment, and the continuation of that legacy while drawing attention away from other unresolved issues or concerns to the student body (Clinton News, 1946; 1948a; 1948b).

Taylor's candidacy and subsequent election is significant because it was one of the rare moments when African Americans ascended to an elected position of leadership while serving a constituency in which they were overwhelmingly in the minority. His success is one of few examples in the 1940s in which a constituency elected a representative who had the ideals, vision, 
and passion worthy of their vote. Pete Taylor was viewed as the individual who could put forward an agenda that could enhance their educational experience while maintaining an ethos that commensurated with the mission and values of the institution. The person they entrusted in that position of leadership just happened to be African American.

\section{Fostering a Culture of Brotherhood}

DeWitt Clinton High School historically fostered a culture of brotherhood. The exact numbers of Black students enrolled are difficult to determine, because school records did not use race as an identifiable trait and yearbooks were not inclusive of the entire student body. Additionally, it is not always possible to identify a person's racial identity from yearbook portraits and photographs of large groups from a distance. Of the 23 young men who were in the inaugural class of 1900, all were White but one of them, William Anthony Aery, was a dedicated servant for equality and the education of the Negro (Pelisson, 2015).

Aery served as a professor and director of education at the Hampton Normal and Agricultural Institute for Negroes and Indians, (now Hampton University in Hampton, Virginia, for 33 years before retiring in 1939. Prior to his tenure, he served as Booker T. Washington's press secretary during his tours of the southern U.S. For 20 years, Aery wrote articles on Black life and the education of the American Negro and served as editor of the Southern Workman monthly published by Hampton Institute. Much of his scholarship highlighted many accomplishments of Black Americans in the face of racism during the era of legalized segregation. His work served as inspiration to his students to succeed and demonstrated a lifelong commitment to social equality. On one occasion, Aery returned to his former high school and lectured on the importance of brotherhood and upholding the task of challenging society's cultural norms. His accomplishments unequivocally reflect the education and ideology promoted at DeWitt Clinton (Aery, 1915; New York Times, 1963).

Perhaps more than any other high school, the student body at DeWitt Clinton closely reflected the ethnic diversity of New York City and in many respects the world. Clinton students constantly challenged or expressed concern about discrimination and injustice. Hollywood films such as Crossfire and Gentleman's Agreement addressing this sensitive topic were published in the Clinton News, the student newspaper. Other concerns over discrimination were expressed through artistic endeavors in the Magpie, the schools' literary journal. In the 1930s, countless students wrote essays on the subject, including Irving Hellerman, who articulated the ugly realities of the racial struggles in contemporary America. In his piece, he deftly noted that the nations' economic struggles contributed to the undermining of race relations and any semblance of national brotherhood. Hellerman even offered solutions to solve the nations' economic woes. The publication of this and other essays demonstrate that some students at Clinton were cognizant of the discrimination that undermined the practical elements of brotherhood (Hellerman, 1937; Phillips, 1947).

Clinton High School set the standard for equitable race relations in secondary schooling. In the 1920s and 1930s when the presence of African Americans was steadily increasing, rarely were there any published reports of any racial discord. Even though many student clubs and organizations revolved around sociocultural identities and representation, the administration did enforce a culture of cooperation and understanding established by the school's larger culture. For example, the 
Hebrew Society, the Newman Club, and the Frederick Douglass Society held joint meetings in the spirit of promoting brotherhood and tolerance (Pelisson, 2015).

The Clinton News also reinforced a culture of integration by publishing accomplishments of African American alumni, publicizing educational opportunities, and scribing editorials on racial discrimination. In 1940, during a joint meeting between the Jewish Discussions Club and the Fredrick Douglass Society, Jack Baker, a former editor of a Berlin newspaper, was invited to give a lecture on interracial hatred and demonstrated how racism in America was transmitted abroad and contributed to the distorted perception of Blacks. He noted, "Most Europeans have a distorted view of the Negro as inferior whom they consider in the light of bandleader, singer, or fit only for any type of menial labor." Negro inventors and scientists like Garret Morgan, Lewis Howard Latimer, and Granville Woods created and patented devices that advanced the industrial revolution in America during the early $20^{\text {th }}$ century, yet these were completely lost. But these racist ideologies harbored by many were challenged on a global stage during the 1936 Olympic Games in Berlin by Jesse Owens who won four gold medals in various track and field events, crushing Adolf Hitler's myth of Aryan Supremacy. Owens' success also demonstrated that Blacks and Whites could work together and succeed when all individuals are premeditatively invested in that goal, since two of his relay team members were White. Mr. Baker concluded his oratory remarks by stating, "Don't condemn an entire minority because of the fault of the individual. Anti-Semitism and all other attacks on minorities are merely smoke screens to hide economic battles and the gain of power and influence for the perpetrator. We must burrow deep to find the roots of evil" (Clinton News, 1940, p. 1). Baker's lecture addressed some of the motivations behind bigotry and how resistance against manipulation was necessary to maintain a progressive society. The fact that these two organizations with varying objectives could unite and co-sponsor Baker's address is a testament to the progressive culture of the school. (Clinton News, 1940; Dyerson, 2001; Edmonson, 2007).

Another influential teacher enveloping the spirit of brotherhood includes Renaissance art enthusiast and aficionado of modern swing, Max Diamond, who also served as the faculty advisor to the Frederick Douglass Society (named after the famous Negro abolitionist and leader). Diamond noted, "I am very interested and concerned with the Negro boys in Clinton and have always been opposed to any sort of racial or religious discrimination." He also added, "I might add that this discrimination is most detrimental to a democracy. I think that our students should be proud of Clinton's tradition of freedom, liberalism, and lack of discrimination" (Clinton News, 1940, p. 4). Diamond's philosophy also permeated his teaching philosophy as he encouraged students to express their art (i.e., voice) without conforming to the sensibilities of others. His position to embrace students, especially Black students, in their artistic and political context is nothing short of incredible when considering the assumption that few White teachers during this time period inspired their Black students to pursue their dreams. This would perhaps explain why DeWitt Clinton High School produced so many successful Black students prior to the legal deconstruction of racial segregation in public schools in 1954 (Clinton News, 1940).

Clinton students were expected to excel and continue their studies in higher education. The unofficial school motto etched in yearbooks and the student paper was "college or bust." Those who did not continue their studies in higher education were encouraged to excel beyond the limits of their chosen professions. When educational opportunities arose, notifications were enthusiastically announced in the Clinton News. One announcement noted that Howard University, 
the prestigious historically Black college located in the District of Columbia, was having its annual Scholarship Examination. The notice indicates the scholarship was open to any Negro high school senior or anyone (which suggests non-Negro students) who met the eligibility criteria (Jacobs, 1945).

The preponderance of brotherhood in the school's culture and the impact of the teachers on the young men, particularly those who were African American, are reflected in their aspirations documented in the yearbooks. Most of these young men were part of clubs and organizations that reflected the mission of the school: to train a generation of leaders. Nearly all the young men in the yearbooks identified a post-secondary institution as the next step in their lives. The class of 1946 is particularly noteworthy because they were the first postwar senior class unencumbered by the prospect of enlisting in the military to join the war effort. Unlike the uncertainty of previous graduates, at their feet lay an abundance of career options. Some of their ambitions were quite explicit. John D. Cosby identified his nickname as "Brilliant," aspired to be a mechanical engineer, and identified NYU as his school of choice. Louis Duckett, who also listed NYU as his college of choice, competed in varsity soccer and was a member of the medical society, did not mince words regarding his future. He noted, "To be a doctor is my aim to this profession I bequeath my name" (Clintonian, 1946, p. 22).

The Frederick Douglass Society seemed to instill a heightened sense of racial pride in some of its members. Harold S. Mercer, who identified CCNY as his school of choice and was a member of the aeronautics club, aspired to become a "Negro engineer." A philosophical Elijah F. Powell Jr. who listed Columbia University with plans to become a medical doctor noted, "Common sense is the strive in life." William "Willie" Williams recorded a lawyer as his career goal and provided a statement that reflected the racial pride and overt nationalist attitude shared by many young Blacks when he stated his desire to "be a credit to my parents and to my race." His quote and membership in the Douglass Society underscores the strong sense of identity that many of these young men had, despite being in a larger culture with few role models of a similar racial characteristics. Since the Society was interracial, it demonstrated that personal spaces organized, or at least informed by, students could include non-Negroes who were supportive, had shared values, and were willing to engage in intellectual and social discourses that did not disturb the individual narratives or visions of its members (Clintonian, 1946).

The culture of DeWitt Clinton encouraged students to conduct themselves as upstanding citizens. With such a large, racially diverse student body, there were few incidents of racial strife. One young man who attended Clinton in the 1940s recalled, there was never any [racial] trouble but each group, particularly in the cafeteria, generally speaking "kept to itself" (Clinton News, 1947; New York Times, 1960; Pelisson, 2015). In fact, in 1946, newly assigned principal John Walsh commended the student body for the extremely low disciplinary cases for which he and the rest of administrative staff were "gratified and even mystified." This sentiment was echoed by his predecessor, John Clark, who served for 17 years before retiring. However, there was an incident in which two students from a rival high school were attacked by at least 10 Clinton students. Principal Walsh, frustrated and embarrassed by the situation, condemned the students with a statement in the Clinton News. He noted, "I hope that every boy in our school will put his heart into seeing that such disgraceful actions are not repeated." 
The comment remarked earlier by the student and principal Clark suggests that students embraced and tolerated each other in accordance to school policy while on campus. But, for a minute few beyond the school grounds, their behavior differed greatly. As articulated by principal Clark, the percentage of disciplinary actions for a student body of this magnitude demonstrates that a majority of the students understood and respected the halls where education was exercised and what it meant to be a Clinton student.

Clinton students underscored their unofficial position as a model of intercultural and interscholastic cooperation when a trip sponsored by the Congregational Christian Committee on Church and Race sent eight delegates from upstate New York to visit the high school. The purpose of the trip was to promote and examine successful models of interracial relations. The group sat in a history class on wage-price inflation and toured various offices, including the library and lunchroom. It was quite evident that Clinton High School, with a student body of more than 5,000, was doing a good job of cultivating brotherhood. This culture allowed Black boys to compete in varsity athletics, such as swimming and tennis, which were historically underrepresented by Blacks and less receptive to racial integration than other team sports. However, their participation contributed to the success of these championship teams (Weingart, 1948).

\section{Integrated Athletic Varsity Teams}

For as long as it was sponsoring varsity athletics, Clinton always fielded integrated teams. The basketball teams were exceptional and routinely racially integrated from the 1920s and 1930s, as were club sports such as swimming and tennis. Private swimming and tennis clubs have historically restricted Blacks and public venues were not always immediately accessible. There was more flexibility and opportunity with tennis, but swimming was another matter. The opportunity to participate, much less learn how to swim, was limited, thus hindering Blacks from auditioning for these teams. It's startling to find Blacks competing on these teams at Clinton. In 1946, the DeWitt Clinton swim team, which featured at least three Blacks, won the Bronx-Manhattan title by finishing the regular season undefeated (Titunik, 1945).

Basketball was the most accomplished sport at Clinton. The varsity team managed to win 12 PSAL championships between 1903 and 1947 (an average of one every four years), but athletics at Clinton served a greater purpose. The integrated varsity teams at Clinton prepared their students to become pioneers at the collegiate level of athletic competition and beyond. The first and second African Americans to compete in varsity basketball at Columbia University were Clinton alumni John Howard Johnson in 1918 and George Gregory Jr. in 1928. Gregory was the first African American voted All-American in 1931, where he was a teammate of John Wooden of Purdue University, who would later coach the University of California Los Angeles to 10 national championships.

In 1950, CCNY became the first racially integrated team to win the national championship of college basketball. Three players on that team, Arthur Glass, Mike Wittlin, and Ed Warner, were DeWitt Clinton High School graduates. Without question, their experiences competing on integrated teams at Clinton better prepared them for the transition of adjusting to life at an integrated college where they could immediately have an impact on the team's success (Ivy League Sports, n.d). 
Eddie Warner deserves individual attention. The Clinton News describes Warner, a six-footthree forward as "Leopard" Ed for his athleticism and keen sense of awareness on the court. Despite being undersized at his position, he had the ability to rebound the basketball with ferocity over taller opponents. Warner was an exceptional player who was offered athletic scholarships to Long Island, New York, and Fordham Universities. However, Warner had his sights set on a career beyond athletics and utilized these academic opportunities to improve his life and social-economic standing. It was in the DeWitt Clinton spirit that he set his sights on attending St. John's College (now University) because it would best prepare him for a potential career as a dentist. Warner ultimately decided to attend CCNY, but what prepared him for the athletic, academic, and social challenges of playing on a racially integrated team during a time when very little in society was integrated was his experience at DeWitt Clinton and competing in the Public Schools Athletic League (Clinton News, 1948).

The culture at DeWitt Clinton prepared their student-athletes to pursue higher education. That higher component of education was immersing a student population into social settings in order for them to interact with individuals from varied backgrounds and share ideas, experiences, and personal narratives that many did not achieve until higher education. The boys at Clinton seemed to be well-prepared to not only make their mark in a changing world, but to lead it as well (Weingart, 1948).

When social issues arose, it was student athletes who were leaned upon to serve as ambassadors to the cause. A senior drama class created a play entitled "Rowdyism" to address reallife issues affecting the campus. The intention of this production was to bring awareness of disruptive behavior and to offer solutions. Though the performances were executed by drama students, it was members of the football and basketball teams that initiated a discussion at the conclusion about racy topics of crime prevention and "rowdyism." Though details of their role are limited, they were probably chosen because of their maturity, level of visibility on campus, and the respect they commanded from their peers (Shepard, 1940).

In another act of service with basketball at its center, Clinton and its Northwest Bronx rival set aside their differences for a charitable cause. On January 11, 1945 Clinton played its first ever night game at home against Evander Childs High School. At the conclusion of the game was a dance that featured a live band in the gymnasium in which students from both schools attended. Clinton soundly defeated Evander 51-17, but most importantly, the two-thousand patrons in attendance raised $\$ 750$ - $\$ 550$ of the proceeds that were donated to the Pawling A.A.F. Hospital. The crowd was the largest for a Clinton home game in four years and demonstrated how its successful basketball team could serve the community. Unlike Evander, Clinton wasn't designated to serve a particular neighborhood as a "neighborhood school." Most of its students from the time the building was constructed at its Bronx location traveled from Manhattan. A significant portion of the student body was from outside the Bronx well through the 1940s. As a result, Clinton did not have the same connection to the immediate neighborhood like its peer institutions: psychologically through its student body, or geographically from its location or its intended mission. As a result, community building was largely confined to the campus. Charitable causes usually involved pairing with other schools or organizations that served regional and national interests. So, when Clinton was involved with a charitable cause it was usually prominent, garnered considerable attention, and was successful. During World War II, the Clinton community purchased more than $\$ 196,000$ in bonds and stamps used to fund a bomber plane named "The Spirit of Clinton" and an Army jeep. 
This noteworthy accomplishment garnered regional attention by the New York Sun. The school also demonstrated leadership by raising funds for other charitable causes. During one collection for the United Nations Children Drive, a teacher noted that students' financial response in his class section were low because they were perhaps exhausted from "the numerous collections made this term" (Hoffer, 1944; Smolen, 1948; Viejo, 1945).

\section{Conclusion}

The DeWitt Clinton student body continued the tradition of supporting charitable causes and fostering a culture of interracial cooperation over the next several decades despite numerous challenges, including a huge demographic shift. In 1950, Clinton had a student body that was 70\% White, the highest number since World War II. Over the years, the population of White students declined dramatically, eroding the school's ethnic diversity. As the racial demographics of the Bronx shifted, so did the demographics of its high schools. Even though Clinton was not a neighborhood school and had no geographical restrictions (any student in the city could apply for admission), it was adversely impacted by what was happening in other communities. In the 1960s, an influx of Puerto Ricans altered the landscape of the borough to which Clinton was the beneficiary. Puerto Ricans provided a balance to the racial distribution of the student body. In 1972, the composition of the student body was 37.2\% Black, 33.8\% White, and 29\% Puerto Rican (Hofmann, 1966; Maeroff, 1972).

The demographic shift did not have any bearing, at least immediately, on the quality of instruction, the academically rigorous culture, and the drive of their young men to excel. In 1963, a study by the Office of Scientific Personnel of the National Academy of Sciences noted that DeWitt Clinton High School was fourth in the nation among public schools whose students (308) had earned their doctorate degree. The study evaluated a period from 1957 to 1962 . These students in all-likelihood graduated from high school before 1953. As time progressed, the school remained steadfast in upholding their elevated standards (Terte, 1963).

In 1972, the school was in the midst of a demographic shift that could have potentially incited racial tensions. Alfred Commodore, an African American, and senior on the basketball team student noted, "We get along well with each other... There is a good atmosphere and I don't think there is much tension." Michael Thomas, a junior who aided fellow students and faculty members to patrol the usually trouble-free halls echoed Commodore's thoughts: "What is different about Clinton is that we've grown up more than boys at other schools. There is no gang fighting and you hardly ever see any drugs here" (Maeroff, 1972, p. 49). In 1982, after years of declining enrollment, the school made the challenging decision to become co-educational - the last New York City High School to do so. The rapidly receding academic reputation, substandard student performance, and the financial realities of operating a building designed for 5,000 students with an enrollment of a little more than 2,000 justified the decision.

DeWitt Clinton High School for decades was arguably a leader and a model of a racial utopian learning environment that was academically rigorous, athletically competitive, and culturally integrated. An archetype that existed well before the supreme court-ordered desegregation of public schools in 1954, DeWitt Clinton's history and legacy is a goal that many public schools still struggle to attain today (Maeroff, 1972). 


\section{Dedication}

This article is dedicated to Kobe Bryant (1978-2020) and his daughter Gianna (2006-2020) who was just beginning to love the game that her father inspired me to write, analyze, and appreciate for its history and all its beauty. May both of you rest peacefully in Heaven's basketball court. 


\section{References}

Aery, W. A. (1915). Titustown: A community of Negro homes. The Press of the Hampton Normal and Agricultural Institute.

Allison, M. G. (1921). The Horizon. The Crisis: A Record of the Darker Races, 23(1). 53-120.

Andrews, W. (2001). The concise Oxford companion to African American literature. Oxford.

Arenson, K. (July 2, 1999). City college president forced out by board of trustees under Badillo. New York Times. http://www.nytimes.com/1999/07/02/nyregion/city-college-presidentforced-out-bv-cuny-trustees-under-badillo.html

Bracks, L. L. (2014). The complete encyclopedia of African American history: 400 years of achievement. African American Publications.

Bard, B. (Feb. 1975) College for All: Dream or Disaster? The Phi Delta Kappan

Buder, L. (1972, March 7). Attendance zone altered in 8 Bronx high schools. New York Times. https://www.nytimes.com/1972/03/07/archives/attendance-zone-altered-in-8-bronx-high$\underline{\text { schools.html }}$

Clinton News. (1947, October 3). Clinton fights discrimination: First school to begin parade of petitions to state capital. 
Clinton News. (1947, December 19). A Clinton disgrace.

Clinton News. (1940, March 8). Editor attacks race bigotry. Daniels, R. (2002). Coming to America (2 $2^{\text {nd }}$ ed.). Harper Collins.

Cornog, Evan. (1998) The Birth of Empire: DeWitt Clinton and the American Experience, 17691828. Oxford.

Dyreson, M. (2001). American ideas about race and Olympic races from the 1890s to the 1950s: Shattering myths or reinforcing scientific racism? Journal of Sport History, 28(2), 173215.

Edmonson, J. (2007). Jesse Owens: A biography. Greenwood Press.

Hellerman, I. (1937, June). Red, white, black. The Magpie, 21(2), 72.

Hine, T. (1999). The rise and fall of the American teenager. Bard Press.

Hoffer, H. (1944, January 7). Purchase of medium Bomber and Jeep becomes a reality as Clinton easily surpasses both quotas. Clinton News.

Hofmann, P. (1966, April 4). Rising Hispanic migration heightens city tensions. New York Times.

Ivy League Sports. (2015, March 31). Black history timeline for Columbia history. Ivy League Sports. http:/www.ivvleaguesports.com/historv/Blackhistorv/2005-06/columbia/timeline

Jacobs, R. (1945, November 1). Howard University offers scholarships. Clinton News. 
Jet. (1972, March 23). Black accounting group honors five at meeting.

Jet. (1973, June 7). Prominent Black architect dies in New York City.

Lemming, D. (1994). James Baldwin: A biography. Knopf.

Maeroff, G. (1972, May 17). Clinton High, at 75 maintains its tradition. New York Times.

Martin, D., \& Lowery, R. (2001, July 27). First Black fire commissioner dies at 85. New York Times.

New York State Legislature. Chap. 492. Laws of the State of New York, $123^{\text {rd }}$ Session, Volume II. Albany, New York: New York State. 1900.

New York Times. (1960, October 1). 500 youths in riot after Bronx game.

New York Times. (1963, October 17). William A. Aery, educator was 81. https://www.nytimes.com/1963/10/17/archives/william-a-aery-educator-was-81-hamptoninstitute-exaide-diesserved.html

Pelisson, G. J. (2009). The castle on the parkway: The story of New York City's DeWitt Clinton High School and its extraordinary influence on American life. Hutch Press.

Pelisson, G. J. (2015). Notable alumni. DeWitt Clinton Alumni Association.

Phillips, F. (1947, October 24). Hollywood vs. hate. Clinton News. 
Ravitch, D. (1974). The great school wars: New York City, 1805-1973: A history of the public schools as battlefield of social change. Basic Books.

Schomburg Center for Research in Black Culture. (n.d.). Shelton Hale Bishop Collection 19451957. New York Public Library.

Shepard, L. (1940, April 12). Senior play dramatizes rowdyism. Clinton News.

Smolen, H. I. (1948, May 14). Clinton responds to UN children drive. Clinton News.

Terte, R. H. (1963, November 28). Stuyvesant no. 1 in alumni Ph.D.'s. New York Times.

Titunik, T. (1945, November 21). Mermen outswim Washington: Capture the Bronx-Manhattan title. The Clinton News.

Viejo, N. L. (1945, January 12). Hoopsters trounce Evander at first basketball dance. Clinton News.

Weingart, S. (1948, May 14). DWC halls climax tour of New York by out-of-towners. Clinton News. 